\title{
High School Learning Problems During The COVID-19 Pandemic
}

\author{
I Wayan Putra Yasa ${ }^{1}$, I Gusti Made Arya Suta Wirawan ${ }^{1}$ \\ putrayasa@undiksha.ac.id,arthasuta@gmail.com
}

${ }^{1}$ Universitas Pendidikan Ganesha, Indonesia

\begin{abstract}
This study describes the problem of learning in high school / vocational school during the COVID-19 pandemic experienced by teachers and students comprehensively. The research method used is a qualitative method, with data collection techniques are interviews, observations, and document analysis. The collected data is then tested for data analysis using the triangulation process of sources and methods. Then the existing data were analyzed through the interactive analysis of Mile and Huberman. Analysis of critical and analytical theoretical data to obtain comprehensive data on learning problems and solutions taken by teachers and other policy makers such as schools and education offices. The results showed that teachers experienced various problems in learning. The first is planning, which is the adaptation pattern with the preparation of the learning implementation plan, the emergency curriculum, the practice of media and learning resources, and the selection of learning applications. The second problem is the implementation of learning, which consists of selecting appropriate learning methods, the psychological conditions of students and teachers, and the assessment system. The third problem of learning support facilities is the uneven availability of the internet network, computers or laptops and handphones.
\end{abstract}

Keywords: Covid-19 pandemic, problems, learning, high school

\section{Introduction}

Since the issuance of the circular letter (SE) No. 4 of 2020, which was signed on March 24, 2020, which this SE contains prioritizing the health of students, teachers, and all school members, students throughout the Republic of Indonesia have begun to carry out learning from home. Indonesians need to change their lifestyle by learning from offline to online. This condition is certainly not manageable in the midst of Indonesia's minimum educational facilities and infrastructure [1]. This makes the problems of education in Indonesia much more complex. It occurs at various levels of education, from primary school to university [2].

An example that can be used as a basis is what happened to historical subjects who had already experienced problems in day-to-day situations. Some of the issues of learning history can be seen from the breadth of the material, short lesson hours, lessons that tend to be daytime, boring learning methods, and other negative views [3]. The problems that exist during the COVID-19 pandemic will undoubtedly increase the psychological burden on students who study history as well as teachers who teach history. Based on preliminary studies conducted on history teachers, there are various ways to do it during existing problems, such as choosing different applications, including using the WhatsApp communication application, google classroom, melajah.id, Moodle, Schoology, Youtube live streaming, google meet, zoom, and other applications[4].

The selection of applications like this certainly creates problems for teachers to prepare and students to follow them. Therefore, the following study is interesting to examine 
how issues exist in the history of apprenticeship at the secondary and vocational secondary levels. Human resource conditions include unequal teachers, unequal facilities and infrastructure, geography, socio-economic conditions of students and others[5]. It makes the learning challenges very complex. This study is also the basis for evaluating the issues of history learning in SMA and SMK so that it becomes a recommendation for future policy makers[4].

The complexity of existing issues does lead to different responses. Every teacher, when analysing the condition of his students, will undoubtedly take additional measures[6]. Video users make interesting parts, diverse tasks and other things among the existing boundaries. These efforts also have a different effect on the improvement of the quality of learning. Therefore, it is necessary to define the most effective solutions to improving the quality of education[7]. Based on the results, it can then be communicated to all teachers in Bali.

A study of picture learning during the Covid-19 period has carried out as Nirwansyah did with the title Covid-19: Point of Range and Portraits of Education, explaining that the Covid-19 pandemic has opened our eyes to the condition of our education in Indonesia, especially in the field of facilities and infrastructure. Infrastructure and teacher quality. Many things must be improved to improve [8]. Furthermore, a study on the Impact of Covid-19 on Online Learning Activities at Christian Universities in Indonesia [9]. This study explains that the Covid-19 pandemic has had a broad impact on learning at Christian universities in Indonesia, where students are forced to learn through zoom, google meet, Moodle, and other applications. However, the reality is that learning cannot work smoothly because of the lack of a good Internet network[10].

Another research that specifically examines the use of online media in learning during the Covid-19 period is Marharjono's study of history learning assisted by Google Class Room in history subjects [11]. This study explains how students and educators can still learn during the COVID-19 pandemic using the Google classroom application. The results of this study also show the weakness of the Google Classroom application because it cannot respond in person and cannot check the status of students. However, just provide one solution because the existing features are quite comprehensive.

Based on the above research results, nothing provides a comprehensive understanding of learning dynamics in the Medium High School, so it is deemed necessary to conduct this research. These findings can then be used as a basis or guide for other teachers to analyze the problems that exist in their schools and get solutions to the issues that exist in their schools. The ultimate objective is to improve the learning of secondary and secondary school history during the COVID-19 pandemic.

\section{Method}

This study is qualitative research that aims to explain learning issues in SMA and SMK during the COVID-19 pandemic. The research steps carried out were determining the research location in SMA and SMK in Singaraja City. The informants used as resource people were history and sociology teachers from the Buleleng District. Collecting data by observing the learning process performed. They analyse various documents used during learning, including curriculum, emerging curriculum, teacher learning implementation plans, list of values, Government regulations and other learning documents.

All data were verified for authenticity based on triangular sources and triangulation methods. Then, after all the data has been collected, the next step is to analyze the data using interactive analytics from Mile and Huberman[12]. Analysis of critical and analytical 
theoretical data to obtain comprehensive data on learning problems and solutions taken by teachers and other policy makers such as schools and education offices.

\section{Results and Discussion}

The COVID-19 pandemic has brought significant changes to various aspects of human life. Education has seen important changes in various aspects, including curriculum, methods, media and learning resources. Teachers and students in the world of education also need to adapt because there is a switch from offline to online. This fast and extraordinary change has positive and negative repercussions. Based on a study of interviews, literature reviews and observations with history and sociology teachers in Singaraja, several essential aspects have changed as a result of this pandemic. From preparation consisting of curriculum and lesson plans. The implementation is composed of media, methods, learning materials, and changes in the evaluation system[13].

\section{1) Planning Issue}

Such a change has had an impact on learning implementation, particularly for teachers and students[14]. Teachers should make important changes to the preparation, implementation and evaluation of learning. At the planning stage, many issues arise, including changes to the program called the emerging program. Curriculum changes then affect teacher preparation for aspects of learning implementation planning, methods, learning media and learning materials. This situation requires teachers to change the administration of learning in accordance with the e-learning implemented[13]. This problem certainly doesn't happen to all teachers, based on interviews with history and sociology teachers in various high schools and vocational schools in the Buleleng district. As far as preparation is concerned, some see this as a problem, but others do not. Change is seen as a problem for new teachers or primary teachers who face barriers in technology. In the meantime, teachers who are good at technology and have sufficient experience are viewed as natural[15].

Based on the analysis of several teacher learning implementation plan documents, interesting things were found, namely the discrepancy between what was stated in the plan and the reality of its implementation. The steps of implementation and reality in synchronous and asynchronous virtual classrooms are vastly different. The results of the observations also show that teachers intend to use Google classrooms or meet through Google Meet, for instance, but they actually use What Apps Group. According to the teacher, the situation was caused by the state of the students who were not prepared because the Internet network or quota did not exist. This condition has been further strengthened by a call from school or government to use learning media that require a small quota[10]. The policy has an impact on the learning process that is not optimal given the problems students face. Teachers are also confronted with the economic conditions of parents of students who are experiencing economic problems as a result of the COVID-19 pandemic. Especially if you look at Bali, which depends on tourism, the impact is very significant [16].

\section{2) Implementation Issue}

The next issue is implementation, learning, including adapting technology from offline learning into online learning. Interview results indicate that all teachers have difficulty managing e-learning. Challenges include the type of media used, its management, its control system, and learning issues. At the beginning of the COVID-19 pandemic, teachers still did not understand the types of applications that could use for learning, such as Google Classroom, Moodle, Schoology, which teachers commonly know as the What Apps group 
[17][18]. Because of this situation, teachers only use What Apps Group as a suggested communication or learning tool. Learning with What Apps Group definitely can't be as much as the Learning Management System (LMS) app for learning. However, this is the best option, given the limitations of the technological adaptation of teachers[19].

Then, after entering the new school year 2020, the government began to conduct various applications of socializing learning among Google Classroom, Melajah. Id, and more of them. Teachers also take part in various training or workshops, either independently or through school programs or education offices. Through various types of activities, teachers begin to adapt to various existing learning applications. Teachers are gradually increasing the quality of their learning. After getting to know the application, the teacher also began to apply it in learning. This condition causes learning that was initially monotonous to become more interactive and fun. As admitted by students in several schools in SMA and SMK in Buleleng Regency, students feel that teachers are starting to use different applications in the new school year. This condition makes students not bored with learning. Teachers are starting to use synchronous applications in learning that allow students to interact with teachers, as was done by high school teachers in Singaraja. The google meeting application is often an option in learning because it allows interacting with students directly[18].

Among the various available applications, most teachers use Google Classroom and which Group applications in learning. Several reasons motivate teachers to choose to use Google's classroom app, including First, Keeping up with technological developments. Amid this pandemic, teachers are also encouraged to follow the development of existing technology; the use of google class rooms is a choice that must make so that organizational learning runs well. The work of teachers to evaluate the student learning process is becoming quicker with digital technology. Students will also receive lessons recorded directly via e-mail, which is convenient and easy to access. As long as the Internet network is available and gadgets are adequate, Google Classroom can be accessed anytime and anywhere. This platform is easy to use even with children who are still in preschool or senior teachers; of course, with some training and adaptation to digital platforms. Secondly, more efficient learning. Google Classroom makes learning systems and processes more efficient, saves time and effort, and is cheaper. Through online learning, the distance between home and school or between teachers and students is only a few stages. Third, practice self-reference for your followers. The supervision system reduces the process of eLearning activities [20], [21].

Therefore, students should be able to be actively involved and more independent. The use of features such as these, if properly maximized, will build children's learning abilities. Ultimately, children are able to adapt to knowledge faster. Fourthly, can count on other functions simultaneously. Because it has a base of Google, the largest search site, Classroom has benefits in terms of complementary functionality. We can use these tools while executing Classroom, such as saving documents via Google Drive, convenient and safe. The use of Google Forms is also very suitable as another solution to assess student learning outcomes. Student scores are computed and accumulated faster. If the teacher agrees, students may even know their notes once they submit their work. We all know that teachers' administration is often a heavy burden. Google Classroom makes it simple with its additional features. Fifth is distance learning. Besides describing a modern learning system, Google Classroom is a usable form adapted to the digital age as it is today. Computerisation has developed into a way of life[22]. Paired with the new natural conditions that suck us deeper. Sixthly, practical places to brainstorming. Of course, it is not only appropriate to use it as a means of learning where the interaction is only between teachers and pupils. The atmosphere of peer collaboration that exists in conventional classrooms can always be present through Google Classroom. 
Discussions, brainstorming sessions and presentations are even easier to complete online than offline. Students are no longer required to install a projector or connect cables everywhere. Just turn on the laptop, open the presentation app and activate the sharing screen.

The existence of applications such as google meetings and zoom meetings is a beautiful choice among students because they no longer do many questions but have various choices. All students cannot accept this condition due to differences in economic status. For students in schools in cities with middle to upper economic parents, this is not a problem. However, for teachers with middle to lower economics and located in remote villages, the What Apps Group learning media is still the primary choice. This situation cannot be separated from the fact that e-learning has advantages and disadvantages[23].

The advantages of e-learning are that firstly it can be accessed easily. Use a smartphone or other technological device such as a laptop that is connected to the internet. You can already access the material you want to learn. By implementing e-learning, you can carry out learning activities anywhere, anytime. The second Cost is more affordable We all want to increase knowledge without financial constraints. With an internet data package, you can access various learning materials without worrying about missing a lesson if you don't attend. It is recommended that you register as a member in e-learning because member fees are cheaper than taking lessons or courses at learning institutions. Third, flexible study time, usually most people who want to learn more do not have enough time. One reason may be that your time is already being used for work. Digital-based learning or e-learning is the solution. Time to study can be done at any time without being tied to study hours. Fourth, Broad Insights, by implementing e-learning, of course, you will find many things that you didn't know before. This is because some of the subject matter available in e-learning is not yet available in print media, such as books that are often used in conventional teaching and learning methods. This is different from face-to-face learning, which is done by reading books[20], [24].

3) Evaluation Issue

The next very important issue concerns evaluation. This evaluation problem is related to the certainty of meeting learning goals. Because of the COVID-19 pandemic, it is difficult for teachers to ensure that students reach their learning goals. Because the teacher cannot be sure whether the student has worked on the given issues independently, it cannot separate diverse conditions from the students. Some students have signal or quota issues, and some have issues with their mobile phone or computer, and their learning environment is not conducive[13].

Based on the analysis of document data and interview results, there is a perception that student scores during this pandemic cannot be used as a benchmark for the actual conditions of existing students. Many students are able to respond not because of their abilities, but because of the help of others or the Internet. All three aspects of evaluation are cognitive, affective and psychomotor. Cognition is with the honesty of students and the attitudes that students have, which are very difficult to monitor. It also has an impact on student competencies. Teachers have major problems in the area of assessment[13][25].

\section{4) Problem Solving}

However, for the sake of prioritizing health, this online learning continues to be carried out. Of course, by improving the quality of teachers through various training. As has been done by teachers throughout Indonesia in collaboration with the Google Suite for Education application, they conduct training on optimizing the use of Google features with education accounts. All existing data is stored online to ensure data security from being 
deleted or lost[22]. The Melajah. id application also offers the same thing to teachers in Bali to use the application in learning at school. The History and Sociology teachers also did the same thing so that the learning that took place also went well.

The school also improves the quality of learning by issuing several policies, such as supervising or supervising teachers who teach. The purpose of this supervision is to ensure the quality of learning goes well. Then the next step is to conduct workshops on the preparation of online-based learning tools, review the emergency curriculum implemented in each school. In addition, through the curriculum field, the principal continues to monitor at any time to find out the problems faced by teachers and students in online learning. Homeroom teachers also continue to coordinate with subject teachers if there are obstacles in the implementation of learning. Despite the policies that have been carried out, the condition of our education is still not going well. The government should take more strategic actions such as making internet access free for teachers and students, providing a better internet network, and improving the quality of teachers, other educational facilities and infrastructure.

From the government, there are several solutions issued in order to prevent problems in online learning. We are starting by issuing an emergency curriculum. There is no national final exam for 12th graders-Internet quota assistance to teachers and students. Conduct virtual workshops to train teachers' skills in learning. The whole policy aims to make learning run well[26].

\section{Conclusion}

The COVID-19 pandemic has brought enormous changes in the world of education in Indonesia, especially in Buleleng Regency. They are learning to switch from offline to online causes teachers and students to change their learning approach. Teachers must make changes from the planning, implementation, and evaluation system carried out. This situation provides a solution for learning during the pandemic and creates new problems in the world of education. However, teachers can still adapt and solve existing problems by adapting technology. Various actions are carried out independently or at the discretion of the school and the government. The synergy of these various components causes learning to still run well during the COVID-19 pandemic.

\section{References}

[1] M. Siahaan, 'Dampak Pandemi Covid-19 Terhadap Dunia Pendidikan', J. Kaji. Ilm., vol. 1, no. 1, pp. 73-80, Jul. 2020, doi: 10.31599/jki.v1i1.265.

[2] W. A. F. Dewi, 'Dampak COVID-19 terhadap Implementasi Pembelajaran Daring di Sekolah Dasar', EDUKATIF J. ILMU Pendidik., vol. 2, no. 1, pp. 55-61, Apr. 2020, doi: 10.31004/edukatif.v2i1.89.

[3] D. Suhendra, S. Supriyanto, and S. Safitri, 'Pengaruh Penerapan Media Video Sejarah Terhadap Hasil Belajar Peserta Didik Pada Mata Pelajaran Sejarah Di SMA Negeri 1 Banyuasin 1', Criksetra J. Pendidik. Sej., vol. 8, no. 1, Mar. 2019, doi: 10.36706/jc.v8i1.7443.

[4] S. Syal, 'Learning from pandemics: Applying resilience thinking to identify priorities for planning urban settlements', J. Urban Manag., vol. 10, no. 3, pp. 205-217, 2021, doi: https://doi.org/10.1016/j.jum.2021.05.004.

[5] Y.-P. Yuan, G. Wei-Han Tan, K.-B. Ooi, and W.-L. Lim, 'Can COVID-19 pandemic influence experience response in mobile learning?', Telemat. Informatics, vol. 64, p. 101676, 2021, doi: https://doi.org/10.1016/j.tele.2021.101676.

[6] L. Yekefallah, P. Namdar, R. Panahi, and L. Dehghankar, 'Factors related to students' satisfaction with holding e-learning during the Covid-19 pandemic based on the dimensions of 
e-learning', Heliyon, vol. 7, no. 7, p. e07628, 2021, doi: https://doi.org/10.1016/j.heliyon.2021.e07628.

[7] L. D. Herliandry, N. Nurhasanah, M. E. Suban, and H. Kuswanto, 'Pembelajaran Pada Masa Pandemi Covid-19', JTP - J. Teknol. Pendidik., vol. 22, no. 1, pp. 65-70, Apr. 2020, doi: 10.21009/jtp.v22i1.15286.

[8] N. Nirwansyah, 'Covid-19: Titik Kisar dan Potret Pendidikan', SALAM J. Sos. dan Budaya Syar-i, 2020, doi: 10.15408/sjsbs.v7i8.15802.

[9] E. Windhiyana, 'Dampak COVID-19 Terhadap Kegiatan Pembelajaran Online Di Perguruan Tinggi Kristen Di Indonesia’, Perspekt. Ilmu Pendidik., vol. 34, no. 1, pp. 1-8, Apr. 2020, doi: 10.21009/PIP.341.1.

[10] M. Roman and A.-P. Plopeanu, 'The effectiveness of the emergency eLearning during COVID19 pandemic. The case of higher education in economics in Romania', Int. Rev. Econ. Educ., vol. 37, p. 100218, 2021, doi: https://doi.org/10.1016/j.iree.2021.100218.

[11] M. Marharjono, 'Manfaat Pembelajaran Sejarah Menggunakan Google Classroom Pada Masa Pandemi COVID-19', Ideguru J. Karya Ilm. Guru, 2020, doi: 10.51169/ideguru.v5i1.155.

[12] M. B. Miles and M. A. Huberman, Qualitative Data Analysis. New Delhi, 1994.

[13] M. Maqableh and M. Alia, 'Evaluation online learning of undergraduate students under lockdown amidst COVID-19 Pandemic: The online learning experience and students' satisfaction', Child. Youth Serv. Rev., vol. 128, p. 106160, 2021, doi: https://doi.org/10.1016/j.childyouth.2021.106160.

[14] T. A. Mengistie, 'Higher Education Students' Learning in COVID-19 Pandemic Period: The Ethiopian Context', Res. Glob., vol. 3, p. 100059, 2021, doi: https://doi.org/10.1016/j.resglo.2021.100059.

[15] F. Tuma, A. K. Nassar, M. K. Kamel, L. M. Knowlton, and N. K. Jawad, 'Students and faculty perception of distance medical education outcomes in resource-constrained system during COVID-19 pandemic. A cross-sectional study', Ann. Med. Surg., vol. 62, pp. 377-382, 2021, doi: https://doi.org/10.1016/j.amsu.2021.01.073.

[16] I. W. D. Sumantra, I. M. Suastika, W. Ardika, and I. W. Suardiana, 'The Impact of Corona Virus Pandemic (COVID-19) on Multicultural Life in Tanjung Benoa, Bali', Int. J. Multicult. Multireligious Underst. ISSN, vol. 8, no. 2, pp. 458 - 468, 2021, doi: https://doi.org/10.18415/ijmmu.v8i5.2690.

[17] H. Mulyono, G. Suryoputro, and S. R. Jamil, 'The application of WhatsApp to support online learning during the COVID-19 pandemic in Indonesia', Heliyon, vol. 7, no. 8, p. e07853, 2021, doi: https://doi.org/10.1016/j.heliyon.2021.e07853.

[18] L. D. S. Lapitan, C. E. Tiangco, D. A. G. Sumalinog, N. S. Sabarillo, and J. M. Diaz, 'An effective blended online teaching and learning strategy during the COVID-19 pandemic', Educ. Chem. Eng., vol. 35, pp. 116-131, 2021, doi: https://doi.org/10.1016/j.ece.2021.01.012.

[19] R. Hilburg, N. Patel, S. Ambruso, M. A. Biewald, and S. S. Farouk, 'Medical Education During the Coronavirus Disease-2019 Pandemic: Learning From a Distance', Adv. Chronic Kidney Dis., vol. 27, no. 5, pp. 412-417, 2020, doi: https://doi.org/10.1053/j.ackd.2020.05.017.

[20] T. Muthuprasad, S. Aiswarya, K. S. Aditya, and G. K. Jha, 'Students' perception and preference for online education in India during COVID -19 pandemic', Soc. Sci. Humanit. Open, vol. 3, no. 1, p. 100101, 2021, doi: https://doi.org/10.1016/j.ssaho.2020.100101.

[21] E. Setiawan, B. Sugeng, A. Luailiyah, F. R. Makarim, and S. Trisnadi, 'Evaluating knowledge and skill in surgery clerkship during covid 19 pandemics: A single-center experience in Indonesia', Ann. Med. Surg., vol. 68, p. 102685, 2021, doi: https://doi.org/10.1016/j.amsu.2021.102685.

[22] H. M. Tufo, D. A. Yuen, G. Morra, M. G. Knepley, B. Zhang, and S. Chen, 'Application of HPC and Big Data in Post-Pandemic Times', Earthq. Res. Adv., p. 100006, 2021, doi: https://doi.org/10.1016/j.eqrea.2021.100006.

[23] J. Rix and N. Ingham, 'The impact of education selection according to notions of intelligence: A systematic literature review', Int. J. Educ. Res. Open, vol. 2, no. 2, p. 100037, 2021, doi: 10.1016/j.ijedro.2021.100037. 
[24] M. J. Hossain, F. Ahmmed, S. M. A. Rahman, S. Sanam, T. Bin Emran, and S. Mitra, 'Impact of online education on fear of academic delay and psychological distress among university students following one year of COVID-19 outbreak in Bangladesh', Heliyon, vol. 7, no. 6, p. e07388, 2021, doi: https://doi.org/10.1016/j.heliyon.2021.e07388.

[25] R. M. Strudwick, N. Cushen-Brewster, C. Doolan, and P. Driscoll-Evans, 'An evaluation of the experiences of academics and practice educators who supported radiography students working on the temporary HCPC register during the COVID-19 pandemic', Radiography, 2021, doi: https://doi.org/10.1016/j.radi.2021.07.001.

[26] G. Avanesian, S. Mizunoya, and D. Amaro, 'How many students could continue learning during COVID-19-caused school closures? Introducing a new reachability indicator for measuring equity of remote learning', Int. J. Educ. Dev., vol. 84, p. 102421, 2021, doi: https://doi.org/10.1016/j.ijedudev.2021.102421. 